\title{
A FÖLDFELSZÍNRE ÉRKEZŐ SZOLÁRIS UV-BESUGÁRZÁS ÉS A LÉGKÖRI ÓZON KAPCSOLATA AZ ÉGHAJLATI RENDSZERREL - FIZIKAI HÁTTÉR ÉS TÁRSADALMI, EGÉSZSÉGÜGYI VONATKOZÁSOK
}

\section{RELATIONSHIP OF SURFACE SOLAR UV IRRADIATION AND ATMOSPHERIC OZONE WITH THE CLIMATE SYSTEM - PHYSICAL BACKGROUND, AS WELL AS SOCIAL AND MEDICAL ASPECTS}

\author{
Tóth Zoltán ${ }^{1}$, Páldy Anna ${ }^{2}$, Antal Z. László3 \\ légkörfizikus, vezető főtanácsos, Országos Meteorológiai Szolgálat Marczell György Főobszervatórium, Budapest \\ tudományos munkatárs, Stratolab Kutató, Fejlesztő és Innovációs Kft., Budapest \\ zoltan.toth@stratolab.hu \\ 2PhD, szaktanácsadó, Nemzeti Népegészségügyi Központ, Budapest \\ ${ }^{3}$ kandidátus, tudományos fömunkatárs, MTA Társadalomtudományi Kutatóközpont, Szociológiai Intézet, Budapest
}

\section{ÖSSZEFOGLALÁS}

Gyakori kérdés, hogy van-e kapcsolat a földfelszínre érkező UV-besugárzás és a légköri ózontartalom hosszú távú változásai, valamint az éghajlati rendszer, illetve annak megváltozása között. Az egész problémakörnek azonban nemcsak légkörfizikai vonatkozásai vannak, hanem egész társadalmunkra hatással van. A cikk első részében ismertetjük a szóban forgó komplex légkörfizikai kapcsolati rendszert, és megmagyarázzuk azokat a lényegesebb folyamatokat, amelyek révén az ózonmennyiség változása hat vagy hathat az éghajlat változására és fordítva. Bemutatjuk az ezek következtében tapasztalható és várható tendenciákat is. Utána ismertetjük az UV-sugárzás egészségünkre gyakorolt pozitív és negatív hatásait, illetve az ezekre vonatkozó vizsgálatok számszerűsített eredményeit. Végül az ózonréteg elvékonyodásának társadalmi okait vizsgáljuk, és elemezzük az ózonréteg elvékonyodása ellen folytatott küzdelem társadalmi, gazdasági és politikai tanulságait.

\section{ABSTRACT}

The question whether there is a relationship between the long term variation of UV irradiation reaching the terrestrial surface and the atmospheric ozone, as well as change in the climate system, has been asked many times. In addition to the atmospheric physical aspects, the whole source of issues has effects on our society at large. In the first section, the complex system of atmospheric physical relationships in question is reviewed, and those essential processes are explained through which the variation of ozone quantity affects or can affect the change of the climate and vice versa. Detected and expected tendencies resulted by the processes mentioned above are also introduced. Then, negative and positive health effects caused by UV radiation as 
well as numerical results of related studies are presented. Finally, social reasons for depletion of the ozone layer are studied, and social, economic, as well as political lessons of the struggle carried out against the ozone depletion are analysed.

Kulcsszavak: szoláris ultraibolya besugárzás, légköri ózon, klímaváltozás, rákkeltő hatás, szürke hályog, D-vitamin, betegségteher, ózontörténet, az ózonréteg védelme, társadalmi okok

Keywords: solar ultraviolet irradiation, atmospheric ozone, climate change, carcinogenic, cataract, vitamine $D$, burden of disease, ozone history, protection of the ozone layer, social reasons

Az ultraibolya sugárzásról sok szó esett a sajtóban az elmúlt bő két évtizedben, ezért jelen cikkben nem írunk az alapismeretekröl.

Az UV-sugárzási helyzetről szólva nem kerülhetjük el a légköri ózon állapotával kapcsolatos információkat, a vele való összefüggéseket, hiszen a felszínre érkező és így a lakosságot érő UV-dózis egyik legjelentősebb befolyásoló tényezője a légkör aktuális ózontartalma.

Választ adunk az ehhez kapcsolódó egyre gyakrabban feltett kérdésekre is. Ezeknek van-e, és ha van, milyen kapcsolatuk van a klímaváltozással? Egyáltalán értelmes-e ez a kérdés?

Jól ismert, hogy élettani hatásai miatt az UV-sugárzás fontos tényező a társadalmi folyamatokban, és mára már az egészségügyben is lényeges szerepet játszik, ráadásul egyszerre káros és hasznos tényezőként.

\section{A SZOLÁRIS UV-BESUGÁRZÁS ÉS A LÉGKÖRI ÓZON KAPCSOLATA AZ ÉGHAJLATI RENDSZERREL}

\section{A szoláris UV-besugárzás tendenciái}

Az UV-sugárzás nagy pontosságú, referenciaértékü mérése kényes és drága, a mai automata mérőhálózatok esetén is az átlagnál jóval több időt és rendszeres ellenőrzést, „törődést” igényel (Tóth Z., 2017), és mert légkörünkön áthaladó mennyisége nagyon kicsi ahhoz, hogy szerepe legyen a légkör energetikájában, korábban nem tủnt fontosnak a hálózatszerü monitoringja. A nagyobb érdeklődés szakmai berkekben akkor indult meg, amikor az 1960-as évek végén a hosszú távú adatsorok elemzése az ózon mennyiségének meglepö, folyamatos csökkenését mutatta. Jelentős mérföldkő volt, amikor 1974-ben Frank S. Molina és Mario J. Rowland, akik két évtizeddel később egy harmadik kollégájukkal együtt megosztott kémiai Nobel-díjat kaptak a globális ózoncsökkenés kvantitatív fizikai-kémiai leírásának megalkotásáért, publikálták modellszámításaik eredményeit, amelyek folyamatos és jelentős mértékü globális ózontartalom-csökkenést jeleztek elöre az elkövetkező évtizedekre. Aztán a „nagy lökést” a mára már elhíresült ózonlyuk 1985-ös 
felfedezése adta. Azok a sokkoló mérési eredmények, amelyek szerint az ózon az Antarktisz felett olykor napokra gyakorlatilag szó szerint eltűnt, éppen abban a magasságtartományban, ahol keletkezési mechanizmusa következtében mindig is a legtöbb szokott lenni, sürgetővé tették az UV-sugárzás hálózatszerü folyamatos mérését, hiszen az UV-sugárzásnak az ózonmennyiség erős csökkenése hatására bekövetkező növekedését pontosan nyomon kellett követni. Az első nemzeti mérőhálózatokat az 1980-as évektől hozták létre. Az Országos Meteorológiai Szolgálat (OMSZ) UV-sugárzást mérő országos hálózatát 1994-ben létesítettük négy mérőhellyel (ma hat mérőhelyből áll), és ezzel egyike a világ első tíz UV-monitoring hálózatának. Jelenleg Európa majdnem minden országában müködik UV-sugárzást mérő hálózat (Schmalwieser et al., 2017). Így tehát pontos, mért információnk a lakosságot érő UV-besugárzást illetően csak az 1990-es évek első felétől van. Az 1. ábrán az emberi bőrre hatékony UV-sugárzás éves összegeit láthatjuk az OMSZ öt méróállomására 1995 és 2017 között. Jól megfigyelhető egy enyhén növekvő trend, amely beleillik a nemzetközileg tapasztalható tendenciákba (Tóth-Fekete, 2018). Ez a növekedés meglepő, hiszen ebben az időszakban már megállt az ózonréteg csökkenése, sőt egyértelmű regeneráció indult meg. Akkor miért növekszik mégis az UV-besugárzás? Az egyik ok a légkör szennyezettségének csökkenése. Egyéb mért napsugárzási paraméterekből kiszámítható a légkör rövidhullámú sugárzásátbocsátó képességére jellemző fizikai mennyiség, az ún.

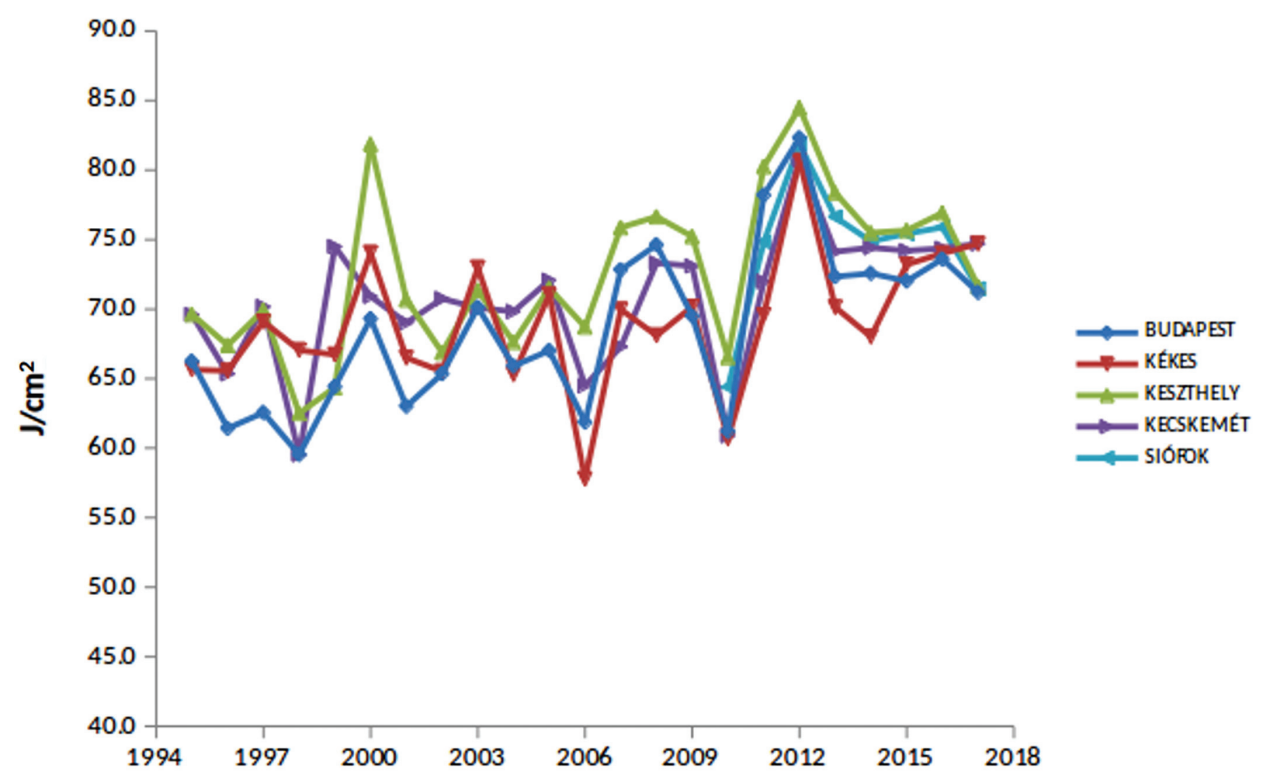

1. ábra. Az emberi börre hatékony UV-sugárzás éves összegeinek változása hazánkban az 1995-2017 időszakban az OMSZ mérései alapján (saját szerkesztés) 


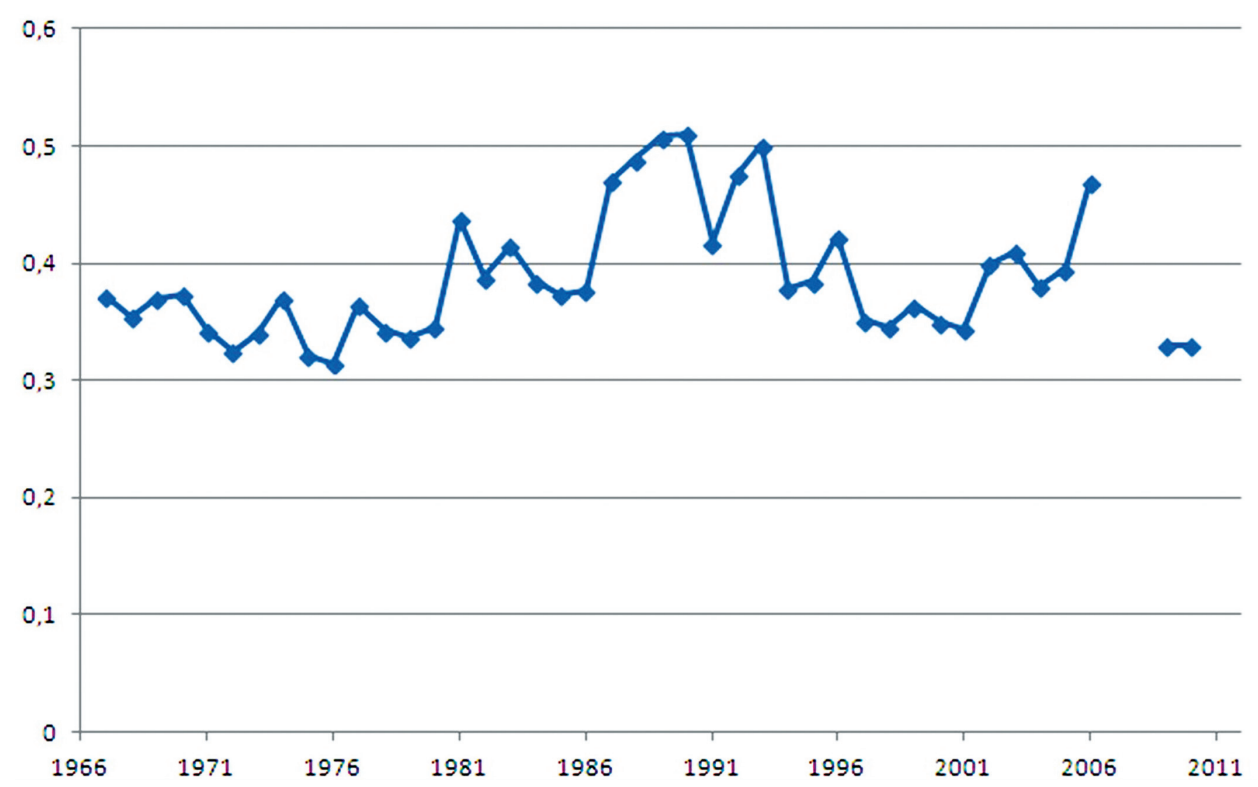

2. ábra. A széles sávú optikai mélység éves átlagainak változása Budapesten az 1967-2011 időszakban az OMSZ mérései alapján (saját szerkesztés)

optikai mélység, amely annál nagyobb, minél gyengébb a közeg sugárzásátbocsátó képessége. A 2. ábrán láthatjuk az optikai mélység éves átlagainak változását 1967 és 2011 között Budapest felett. Jól érzékelhető, hogy a légkör sugárzásátbocsátó képessége csökkent az 1990-es évek első feléig, majd egy enyhén növekvő tendencia figyelhető meg, azaz csökken a légkör szennyezettségének mértéke. Ezt a levegőkémiai mérések is alátámasztják, oka az ipar általános modernizálása, és ezáltal fokozatosan kevésbé szennyezővé válása. Hazánkban a korábbi korszerütlen és erősen szennyező szocialista ipari létesítmények jelentős részét leállították, a tovább is működőket pedig korszerüsítették. Így az UV-besugárzás enyhén növekvő tendenciáját főképp az okozza, hogy a légkör sugárzásátbocsátó képessége javult, és ez az effektus kissé felülmúlta az ózonréteg növekedésének UV-sugárzást csökkentő hatását. Ezt megerősítik Ilias Fountoulakis és munkatársai (2016), illetve Merle Glandorf és munkatársai (2005) eredményei is.

\section{A légköri ózontartalom hosszú távú változásai}

A 3. ábrán a Budapest feletti ózontartalom éves átlagainak a sokéves átlagtól való százalékos eltéréseit tüntettük fel az OMSZ 1969 és 2017 közötti mérései alapján. Jól érzékelhető a csökkenő trend az 1990-es évek közepéig, és onnan kezdve a csökkenés megtorpanása, majd valamiféle regeneráció megindulása, ez utóbbiról 
már rég jól ismert, hogy a Montreali Jegyzökönyvben foglaltak sikeres végrehajtásának az eredménye. A trendet kissé torzítja a Fülöp-szigeteki Pinatubo vulkán 1991-es kitörése, amelynek következtében olyan mennyiségü vulkáni anyag került az alsó sztratoszférába, amely már kimutatható ózoncsökkenést okozott. Ez 19921993-ban hozzájárult az eleve jelen lévő csökkenéshez. A trendről nehéz egyértelmü megállapításokat tenni az utóbbi évtizedre vonatkozóan, de egy évtized nem is elegendő ez esetben megbízható következtetések levonására. A légkörben zajló sok összetett folyamat, mechanizmus, visszacsatolások stb. révén valamely kiragadott fizikai mennyiség értékét, annak változását rengeteg tényező befolyásolja. Ezt jól mutatja a mi budapesti adatsorunk néhány részletének szemügyre vétele. Az 1990-es évek közepéig tartó csökkenés az illesztett trendvonal feltüntetése nélkül is szembetűnő. Nézzük most meg az ózon 1980-as évtized alatti viselkedését! Láthatjuk, hogy abban az évtizedben egyértelmüen növekedés volt tapasztalható. Ez egyáltalán nem azt jelenti, hogy hazánk fölött a világ más részeivel ellentétben nem is volt ózoncsökkenés, hanem azt, hogy ha egy ilyen komplex fizikai rendszerben, mint a földi atmoszféra, kiválasztunk egy fizikai mennyiséget a sok közül, amelyre rengeteg egyéb, eleve sok minden mással kölcsönhatásban és viszszacsatolásban lévő tényező hat, nem minden esetben, vagy nem minden rövidebb időszakra fogjuk a hosszú távon érvényesülő fő effektust látni. Másképpen fogalmazva: a fö effektus elveszhet a sok tényező együttes hatása mellett, és csak elegendően hosszú időszak megválasztása esetén válik láthatóvá.

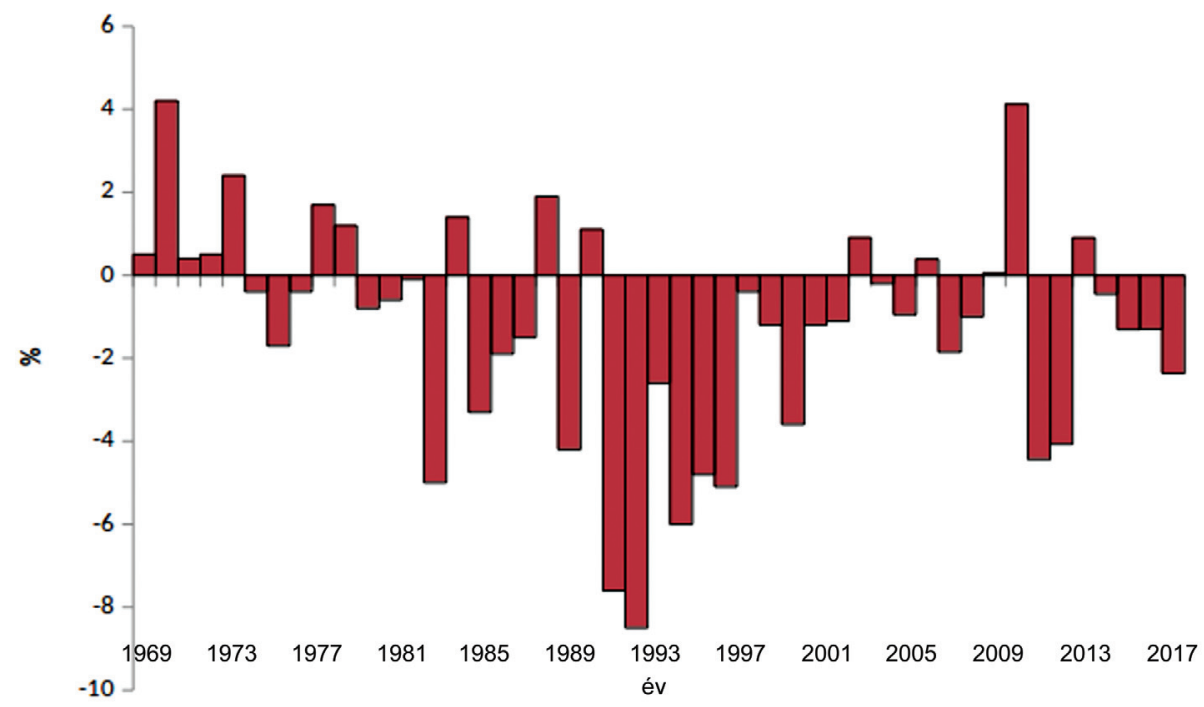

3. ábra. A teljes ózontartalom spektrofotométeres mérésekből számított éves átlagainak százalékos eltérése a sokéves átlagtól Budapest fölött az 1969 (balra)

és 2017 (jobbra) közötti időszakban az OMSZ mérései alapján (saját szerkesztés) 


\section{Az ózontartalom és az éghajlati rendszer kapcsolatának komplex problémái}

Nem szabad azonban elfelejteni, hogy több tényező van, amelyekre vonatkozóan nagy bizonytalansággal ugyan, de tudjuk, hogyan és milyen mértékben kell velük számolni.

Mivel az ózon jelentős abszorbens az ultraibolya és az infravörös sugárzások tartományában, melegíti az alsó sztratoszférát. Ennek következményeként a vertikális hőmérsékleti profil (azaz a hőmérséklet változása a magassággal) a troposzférában tapasztalható csökkenőből a sztratoszféra magasságában növekedőbe megy át. A globális cirkulációt jelentősen meghatározza a vertikális profil. Ez feltételezhetően nagyon hosszú ideig közel állandó volt. Viszont az évtizedekig tartó ózontartalom-csökkenés következtében abban a magasságtartományban, ahol a keletkezési mechanizmus következtében a legtöbb ózon van (durván 15-30km), hosszú távon kicsit alacsonyabb volt az átlaghőmérséklet (és ne felejtsük el, hogy még mindig nem növekedett vissza ,normálisra” az ózontartalom, tehát az effektus - ha csökkenő mértékben is, de - még fennáll). Ez szükségszerüen maga után vonja a nagytérségű időjárási rendszerek mozgásának valamekkora megváltozását (Bojkov-Fabian, 1989). Azt viszont nem lehet pontosan tudni, hogy ez a hatás az ózontartalom-csökkenés megszünte után megszünik-e, vagy a hosszú ideig fennálló alacsonyabb átlaghőmérséklet az adott magasságtartományban vissza nem fordítható változást okoz. A problémát tetézi, hogy a fordított mechanizmus is müködik a légkörben: az alacsonyabb hömérséklet kedvez az ózonmennyiséget csökkentő körülmények létrejöttének a sztratoszférában. Emiatt pozitív visszacsatolás jött létre: a csökkenő ózonmennyiség okozta hủlés további ózoncsökkenést okozott. Mivel egy ilyen komplex bolygóatmoszféra, mint Földünk légköre, rendkívül sokféle „finomhangolás” által müködőképes csak, kérdés, hogy ezek a folyamatok okozhattak-e olyan hosszú távú következményeket a rendszer más szegmenseiben, amelyek jelentősen késleltetik, vagy akár meg is akadályozzák a sztratoszféra megváltozott kémiai állapotának zökkenőmentes megszünését.

Hazánkban további speciális tényező, hogy az utóbbi évtizedekben gyakoribbá váltak a mediterrán beáramlások Magyarország területére, föként nyaranként. Mivel normál esetben az ózon koncentrációja az egyenlítőtől a pólusokig növekszik, a mediterrán légtömeg ózontartalma nagyobb eséllyel alacsonyabb, mint a hazánk felett jellemző érték. E hatás következményét tapasztaljuk is: az utóbbi két és fél évtizedben folyamatosan ózonhiányt regisztrálunk nyaranként. 1992 óta az összes nyári hónapot tekintve azt tapasztaltuk, hogy (az ebből a szempontból négy hónapos nyarakat figyelembe véve) a 108 hónapból mindössze kilencben (!) volt az átlagos eltérés pozitív, de ebből is két hónapot kivéve a pozitív eltérés jelentéktelenül kicsi. A teljes nyári gyakorisági eltérés minden évben negatív volt, azaz a nyári ózonhiány huszonhét éve folyamatosan fennáll. Még csak közelítőleg se lehet megmondani, hogy ez az effektus mennyire fogja fékezni az ózonkon- 
centráció növekedését. Kérdezhetnénk, hogy mi köze a mediterrán beáramlásoknak az ózontartalom változásához, hiszen az előbbiek a troposzféra jelenségei, az ózon túlnyomó hányada pedig az alsó sztratoszférában található, és csak kis mennyiségben van jelen a troposzférában. Nos, a nagytérségü örvényrendszerek a troposzféra jelenségei, de sok esetben magasságuk elérheti a 6-8 kilométert, sőt olykor akár a 10 kilométert is. Ilyenkor már az alsó sztratoszféra anyagával is kölcsönhatásba kerülnek, és főleg néhány speciális ciklonfajtában jelentős mértékü anyagáramlás zajlik le a felső troposzféra és az alsó sztratoszféra között (BojkovFabian, 1989). Ilyen esetekkel szoktunk találkozni az OMSZ ózonmérései során is: nagyon erős frontok esetén az ózon mennyiségében abnormálisan nagymértékü változást tapasztalunk néhány óra alatt.

Továbbá még egy fontos folyamat müködik: az éghajlati rendszer belső autonómiája. Ez azt jelenti, hogy a légkörben hosszú távon (értsd: klimatikus időskálán) mindig történnek kisebb-nagyobb változások minden egyéb külső behatás hiányában is. Ez nem meglepő, sőt szükségszerü, hiszen az atmoszférának mint fizikai rendszernek kötelező megfelelnie az alapvető fizikai törvényeknek, és ennek a folyamatos „változásban létezés” a következménye. Például a légkör az energiaminimum fenntartására törekszik. Ezt a termodinamika II. fötétele értelmében legkönnyebben a világür felé történő hủléssel (energialeadással) tudja elérni, amit a lehető legtöbb hosszúhullámú (távoli infravörös) sugárzás kibocsátásával tud megvalósítani. Ez csak folyamatos „,finomhangolások”, „utánszabályozások" segítségével sikerül a légkörnek. Például az egyensúly fenntartásához, ha nem is minden pillanatban, de hosszabb időszakok átlagában, egyenlőnek kell lennie a légkör által kapott (azaz a légkörben bennmaradó és ezáltal felhasználható) rövidhullámú sugárzási energiának (ami a Napból érkezik) a kimenő (a földfelszín és a légkör által kisugárzott) hosszúhullámú sugárzás energiájával. Az ezt az egyensúlyt befolyásoló bármilyen kis változást a légkörnek ,utána kell igazítania”. Azaz például, ha egy nagyobb területen a bevetetlen területből mezögazdasági területet hoznak létre, meg fog változni a felszín rövidhullámú visszaverő (azaz fényvisszaverő) képessége (albedója). Ez azt jelenti, hogy az addigitól eltérő mennyiségü rövidhullámú sugárzási energia kerül a légkörbe, így a légkörnek különböző „,praktikákkal” kell elérnie, hogy fenntartsa az egyensúlyt. Ezek óhatatlan következményei a légkör mérhető fizikai mennyiségeiben bekövetkező változások. E természetes ,utánaállítások” következményei azok a változások, amelyeket az éghajlati rendszer belső autonómiájának hívunk.

A sztratoszféra működésének vizsgálatával foglalkozó szakemberek az erre a célra kifejlesztett kémiai-dinamikai modellek segítségével korábban kiszámolták, hogy az ózonkoncentráció tapasztalt csökkenése teljesen magyarázható-e az emberi tevékenységgel. Az eredmény érdekes volt: legjobb esetben is csak 70 százaléka volt magyarázható az ózonkárosító vegyületek (freonok és halonok) hatásával (Bojkov-Fabian, 1989). A jelenlegi ismeretek szerint a modellek hiá- 
nyosságai nem adhatnak ilyen különbséget. Ha ezt elfogadjuk, akkor ez azt jelenti, hogy a nem elhanyagolható maradék rész jó eséllyel az éghajlati rendszer belső autonómiájának következménye, azaz egyszerüen a légkör „finomhangolásai”, „utánszabályozásai” miatti változások olyan jellegüek, hogy az ózontartalom bizonyos mértékü csökkenését okozták azokban az évtizedekben. Ez a változás gyakorlatilag független a freonok és halonok hatásától, azaz iparból való kivonásuk után is tart, bár idővel akár fordított irányú változásba is átmehet. Mértékének esetleges jövőbeli változását szinte lehetetlen elöre jelezni, mert az ózon rendkívül kis mennyiségben van jelen a légkörben, és koncentrációját számos tényező befolyásolja. Így csak nagyon bizonytalanul lehet becsülni, hogy az egyéb „rejtett” hatások mennyire szólnak bele az ózonkárosító anyagok légkörből való kivonása következtében fokozatosan „visszanövekedő” ózontrendbe.

Ezek a folyamatok könnyedén okozhatnak kisebb-nagyobb zökkenőket az ózongyakoriság növekedő tendenciájában, de a modellek valószínűségi előrejelzése szerint a legnagyobb mégis annak az esélye, hogy a század végére megszünik az ózonprobléma. Viszont a kialakult helyzet és az eddig történtek arra figyelmeztetnek, hogy egy pillanatra sem csökkenhet a szakemberek ébersége.

Még egy hatással kell számolnunk. Az utóbbi évtizedekben globálisan a sztratoszféra enyhe hủlése figyelhető meg a rádiószondás felszállások mérési sorozatainak feldolgozása alapján, így az OMSZ budapesti és szegedi rádiószondás adatsoraiból is. Mivel az alacsonyabb hőmérsékletek az alacsonyabb ózonmenynyiségeknek kedveznek statisztikailag (azaz a legtöbb jelentősebb ózoncsökkentő hatás létrejöttéhez alacsony hőmérséklet szükséges), ez a hülés lassítja az ózonkoncentráció visszanövekedését.

\section{Hogyan változhat a jövőben a lakosságot éró UV-besugárzás?}

Ma már nem vitatott tény, hogy az ózonréteget károsító anyagokat az egyezményeket aláíró országok teljességgel kivonták az iparból, így mára globális mértékben jelentéktelen a halogénezett szénhidrogének légkörbe juttatása. Azaz, az okot megszüntették, már csak azért kell várni a végeredményre, mert az ózonkárosító vegyületek átlagos légköri tartózkodási ideje igen hosszú, így ha már többet nem is juttatunk a légkörbe, a már ott lévők még sokáig ott maradnak. De utánpótlás hiányában fokozatosan csökken a mennyiségük. Az e célra kidolgozott modellek előrejelzése szerint a legvalószínűbb végkifejlet az, hogy századunk második felében - legnagyobb eséllyel a 2080-as évtizedben - a sztratoszféra kémiájában elöállt zavar megszűnik, és visszaállhat az eredeti állapot. Az utóbbi évtized mérései azonban nem mutatnak javulást, sőt egy kis ózonkoncentráció-csökkenés vagy legalábbis stagnálás időszakában vagyunk, ahogy ezt a 3. ábrán láthatjuk. Ez jól érzékelteti, hogy minden kijelentést és következtetést csak nagyon körültekintő vizsgálatok után és elegendően hosszú időszak elteltével tehetünk. A fentebb em- 
lítettek tükrében meglepően optimistának tủnik a Meteorológiai Világszervezet (World Meteorological Organization) szakértői bizottsága által az ózonréteg állapotáról évente kiadott jelentés (Scientific Assessment of Ozone Depletion) legújabb, 2018. novemberi dokumentumában foglalt elörejelzés. Eszerint az ózonréteg teljes regenerációja a korábbiakban becsültnél várhatóan hamarabb fog bekövetkezni: az északi félteke mérsékelt övében 2030 környékén, a déli félteke megfelelö övezetében 2050 körül, a déli sarkvidéken pedig várhatóan 2060 körül.

A másik fontos kérdés az, hogy a földfelszínre érkező UV-sugárzást befolyásoló más tényezők hogyan fognak változni a jövőben.

A legfontosabb nyilván a Nap által kibocsátott UV-sugárzás mennyisége. Mai ismereteink és a Nap müködését leíró modellek szerint úgy tünik, hogy ez nem fog számottevően változni számunkra beláthatatlanul hosszú ideig, így ezzel a hatással nem kell számolni.

A következő nagy kérdés a légkör rövidhullámú sugárzásátbocsátó képessége, amelyet elsősorban a levegőben lévő szennyezőanyag-mennyiség és a felhőzet határoz meg. Arra utaló jeleket manapság nem lehet tapasztalni, hogy a globális felhőzetben számottevő trendszerü változás volt-e az elmúlt évtizedekben. Az pedig vitatott, hogy az elkövetkező évtizedekben ilyenre számíthatunk-e, így ezzel a hatással most itt nem számolunk. A szennyezettség csökkenő tendenciája nem tarthat akármeddig, hiszen energiatermelés, ipar mai tudásunk szerint nem létezhet szennyezés nélkül. Kérdés persze, hogy mennyit fog változtatni ezen majd a fúziós erőmüvek energiatermelésbe állítása, már ha ezzel egyáltalán lehet számolni a belátható jövőben, mivel egyelőre a folytonos magfúzió fenntartása a nemzetközi kísérleti fúziós erőmüben (ITER) a felmerülő problémák megoldása után mindig újabb problémákat szül. Tehát jelen ismereteink alapján lassuló csökkenéssel számolhatunk. Ez következésképpen az UV-sugárzás egyre lassuló növekedését okozza. Az említett változások olyan csekélyek, hogy azoknál a jövőbeli állapotokat előrejelző modellszámítások bizonytalansága nagyobb. Így csak annyit lehet feltételezni, hogy figyelembe véve az ózontartalom korábban említett szintén lassú várható növekedését, az UV-besugárzás enyhe növekedése lassan megszünik. Ha az ózontartalom eléri a perturbáció előtti állapotot, akkor az UV-besugárzás további tendenciája attól függ, csökkenni fog-e még a légkör szennyezése.

\section{AZ UV-SUGÁRZÁS ÉS AZ EGÉSZSÉG}

Az ultraibolya sugárzás három tartományának eltérő a biológiai hatása. Jelenlegi tudásunk alapján - sugáregészségügyi szempontból - az UV-C és UV-B sugárzás veszélyesebb, mint a kisebb energiájú UV-A, azonban az UV-A sugárzás túlzásba vitt expozíciója hatására is károsodhat az egészség. 


\section{Az UV-sugárzás egészségkárositó hatásai}

Az UV-sugárzás egészségkárosító hatásai közül a legfontosabbak a bőr leégése (fotodermatózis), valamint a szemlencse széli részének homályosodása (szürke hályog, katarakta), továbbá a rákkeltő hatás. Az UV-B sugárzás elsősorban két nem festékes bördaganat (bazalióma és elszarusodó laphámsejtes daganat) kialakulásának kockázatát növeli, az UV-A pedig a festékes bőrdaganatok, a melanómák kialakulását idézi elő.

A klímaváltozással foglalkozó kormányközi testület (IPCC) 4. jelentése (2007) megállapítja, hogy a klímaváltozás egészségkárosító hatásaival kapcsolatban kockázati tényezőként kell kezelni a változó UV-sugárzást (Confalonieri et al., 2007). A túlzott UV-sugárzás összefügg a bőrdaganatok (beleértve a melanomát), továbbá a katarakta gyakoribbá válásával. Az IARC (WHO Nemzetközi Rákkutató Ügynökség) a napsugárzást és az ultraibolya sugárzást az ember számára rákkeltő 1. csoportba sorolta (IARC, 1992). Az Európai Daganatmegelözési Kódex (URL1) javaslata szerint - összhangban az EU daganatmegelőző programjával kerülni kell a túlzott napfény-expozíciót.

A sztratoszferikus ózonréteg csökkenését a Montreali Jegyzökönyvben (1987) foglaltak betartása sikeresen megállította, ezzel jelentősen hozzájárult az UV-sugárzás egészségkárosító hatásainak csökkentéséhez. A részletes elemzések (EPA, 2015) azt mutatják, hogy a Montreali Jegyzökönyv és módosításainak intézkedései nélkül mintegy 14\%-kal lenne magasabb a bőrrák előfordulása világszerte 2030-ig, azaz mintegy kétmillió emberrel több szenvedne ettől a kórtól évente. Növekedne a szürke hályog előfordulása is, és csökkenne az immunrendszer védekezőképessége. A WHO adatai szerint 2000-ben világszerte 200000 melanomás megbetegedést észleltek, és 65000 ehhez kapcsolódó haláleset fordult elö, illetve mintegy 18 millió ember vakult meg szürke hályog miatt (URL2).

A tudományos eredmények azt mutatják, hogy a sztratoszferikus ózonréteg jelenlegi csökkenése folytatódik a következő egy-két évtizedben (a járulékos UV-B expozíció kumulálódása révén), ami növelni fogja a világos bőrű populáció öszszes bőrdaganat-kockázatát a magasabb szélességi körökön (URL3). A jövőbeni ózonszintek és az UV-B sugárzásnak való kitettség modellálására vonatkozó vizsgálatok szerint a $45^{\circ}$-os északi szélesség körül élő európai lakosság körében 2050-re 5\%-kal fog növekedni az összes bördaganat incidenciája.

\section{Az UV-sugárzással kapcsolatos bőrdaganatok előfordulása Magyarországon}

A bőr nem festékes típusú rosszindulatú daganatainak gyakorisága folyamatosan növekvő tendenciát mutat, a tizenhárom vizsgált év alatt mintegy 50\%-kal nőtt az előfordulás mindkét nemben (4. ábra). 


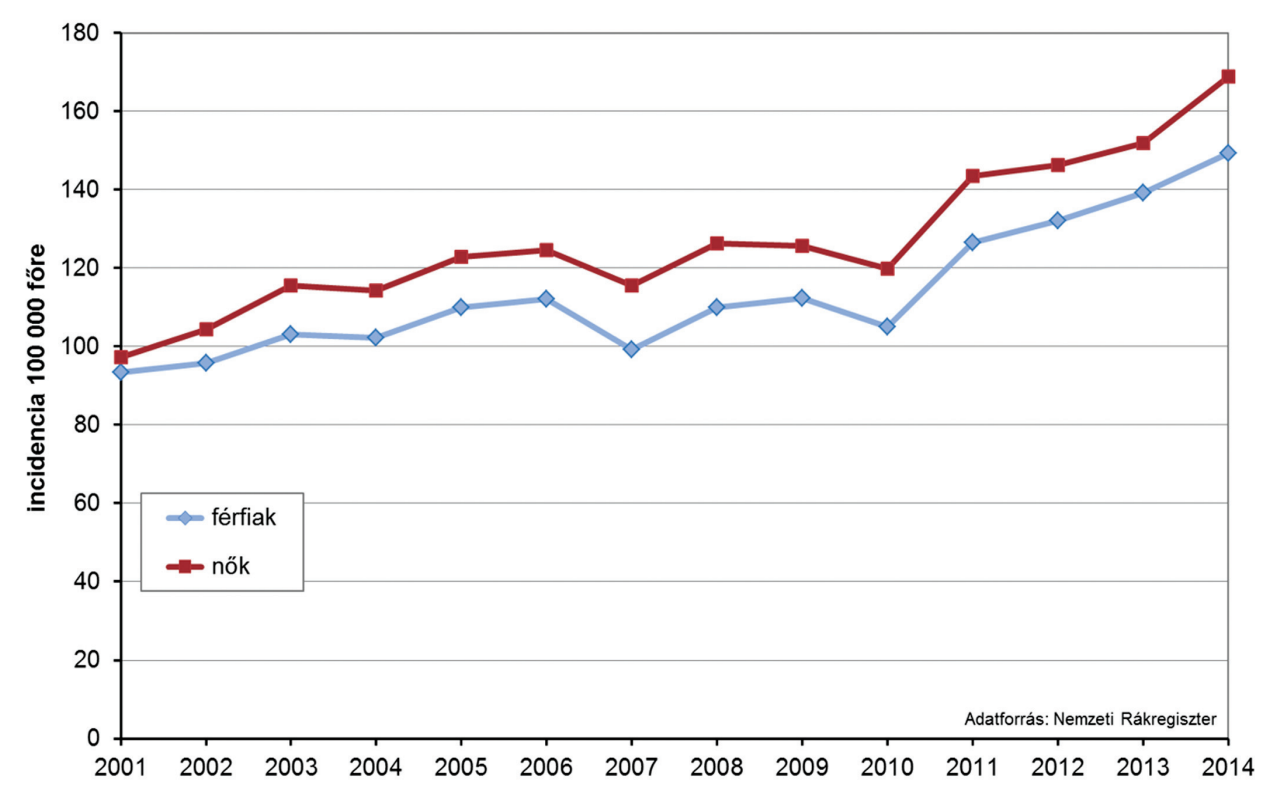

4. ábra. A nem melanoma típusú bőrdaganatok gyakorisága Magyarországon 2001-2014 között (saját szerkesztés)

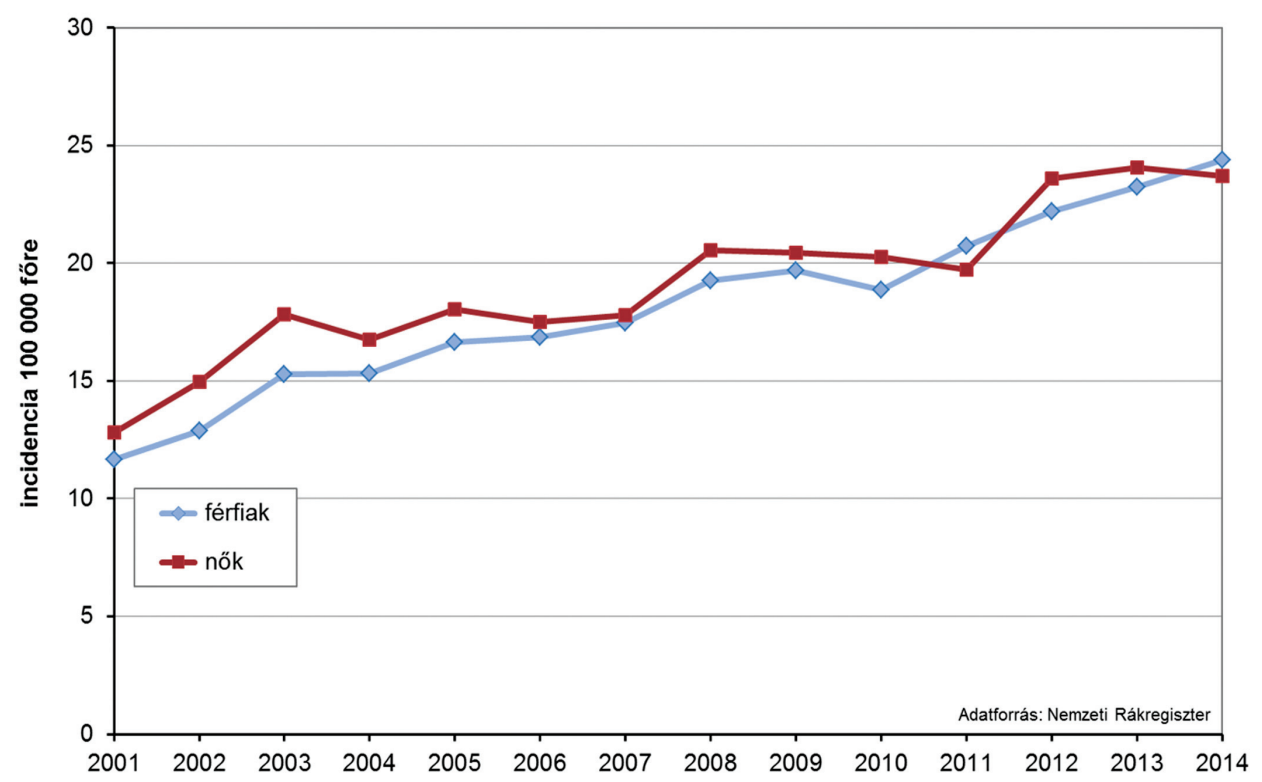

5. ábra. A rosszindulatú festékes bőrdaganatok gyakorisága Magyarországon 2001-2014 között (saját szerkesztés) 
A bőr rosszindulatú melanomájának incidenciája (a Nemzeti Rákregiszterben nyilvántartásba vett új betegek száma) évek óta folyamatosan nő (5. ábra). A melanoma miatti halálozás területi elrendeződésére férfiaknál jellemző, hogy Szabolcs-Szatmár-Bereg, Csongrád és Békés megyében, valamint Sopron környékén az országos átlagnál szignifikánsan alacsonyabb, míg a nyugati országrészben, különösen néhány budapesti kerületben és Komárom-Esztergom megyében magasabb. Nők esetében a nyugati megyékben figyelhető meg kismértékủ halálozási többlet az országos átlaghoz viszonyítva.

\section{A napsugárzás kedvező hatásai}

A napsugárzás számos kedvező hatást is kifejt az emberi szervezetre, javítja hangulatunkat, erősíti szervezetünk betegségekkel szembeni ellenálló képességét. Az UV-B sugárzás a kalcium-anyagcsere befolyásolásán keresztül erősíti csontjainkat, mivel elősegíti a D-vitamin képződését. A D-vitamin az immunrendszer számára is nagyon fontos: hatékony védelmet jelent több daganatos megbetegedés kialakulásával szemben, elsősorban a vastagbél- és az emlőrák esetében ismert ez a kedvező hatás. A mi égövünkön a napsugárzás expozíciója nem elégséges ahhoz, hogy egész éven át megfelelö D-vitamin-ellátottságot biztosítson. A hazai átlagos táplálkozási szokások elhanyagolható mennyiségű D-vitamin bevitelét biztosítják, így a tizennégy orvostudományi társaság közös állásfoglalása ${ }^{1}$ szerint: a megfelelő D-vitamin-ellátottság nem csupán étrendi dietetikai kérdés. A napi D-vitamin-igény változó, függ az életkortól, testsúlytól, élethelyzettől, például a várandósságtól is (Takács et al., 2012).

A túl kevés UV-sugárzás következtében világszerte igen jelentős betegségteherrel kell számolnunk (3,3 milliárd év/DALY²) elsősorban a vázizomrendszeri betegségek, különböző autoimmun betegségek és néhány gyakori rosszindulatú daganatos betegség miatt, amelyeknek közös kockázati tényezője a 25-hydroxyvitamin-D (calcidiol) alacsony szintje. Ezért a D-vitamin-hiányt fontos népegészségügyi problémának kell tekinteni, és fontos a megelőzés elveinek ismerete (Páldy, 2016).

Mindezek alapján egyre több bizonyíték támasztja alá, hogy a napsugárzásnak jelentősebbek a kedvező hatásai, ami nagy kihívást jelent a napsugárzás elleni vé-

${ }^{1}$ A konszenzus kialakításában részt vevő társaságok, egyesületek: Magyar Allergológiai és Klinikai Immunológiai Társaság, Magyar Dermatológiai Társaság, Magyar Endokrinológiai és Anyagcsere Társaság, Magyar Gyermekorvosok Társasága, Magyar Hematológiai és Transzfuziológiai Társaság, Magyar Hypertonia Társaság, Magyar Ideg- és Elmeorvosok Társasága, Magyar Kardiológusok Társasága, Magyar Laboratóriumi Diagnosztikai Társaság, Magyar Menopauza Társaság, Magyar Nefrológiai Társaság, Magyar Onkológusok Társasága, Magyar Osteológiai és Osteoarthrológiai Társaság, Magyar Primer Prevenciós Orvosi Egyesület.

${ }^{2}$ DALY: Disability Adjusted Life Years: rokkantsággal korrigált elveszített életévek 
delem korábbi évtizedekben széles körben hangoztatott paradigmájával szemben (Reichrath-Nürnberg, 2009). De mielőtt megváltoztatnánk a napsugárzás elleni védelemmel kapcsolatos politikát, meg kell fontolni azt, hogy a napsugárzás számos kedvező hatását mind ez ideig elsősorban megfigyeléseken alapuló epidemiológiai vizsgálatok során mutatták ki. E vizsgálatok bizonyító ereje azonban jóval kisebb, mint a klinikai vizsgálatoké, amelyek pontosabban tudják vizsgálni az ok-okozati kapcsolatokat. A Nap gyógyító erejének egyértelmü bizonyítására további klinikai vizsgálatok szükségesek a dózis-hatás összefüggések pontosítása érdekében.

\section{Mit javasolunk?}

A D-vitamin-képződéshez szükség van napi 15-20 perc napsütésen tartózkodásra vagy maximum napi 4000 egység D-vitamin-bevitelre. Azonban nem déltájban, a tűző napon kell tartózkodni, a szabad levegő és a szórt sugárzás is elegendő.

Mindezek alapján javasoljuk a rendszeres szabad levegőn való tartózkodást délelőtt 11 óráig vagy délután 3 óra után. A delelési időszakban, főleg nyáron, magas (>7) UV-index esetén tartsuk be a helyes napozás szabályait!

\section{AZ ÓZONRÉTEG ELVÉKONYODÁSÁNAK TÁRSADALMI OKAI}

Annak ellenére, hogy az ózonréteg elvékonyodását és annak közvetlen okait a természettudósok ismerték fel, az „ózontörténettel” a társadalomtudósok is komolyan foglalkoznak, hiszen az ózonréteg elvékonyodása - számos más környezetben történt változáshoz hasonlóan - végső soron társadalmi okokra vezethető vissza. Az ózonréteg elvékonyodása miatt ma már széles körben ismert anyagok a halogénezett szénhidrogének (CFC), de kevésbé ismertek azok a társadalmi, gazdasági és politikai körülmények, amelyek ennek a szintetikus anyagnak a kidolgozására ösztönözték a gyártókat és a kutatókat. Miután már tudjuk, hogy a CFC használatának milyen következményei lettek (Tóth Z., 2016; Páldy, 2016), érdemes megvizsgálni, hogy milyen társadalmi feltételek tették lehetővé a veszélyes helyzet kialakulását, illetve járultak hozzá ahhoz.

Az „ózontörténet” szorosan kapcsolódik az ételek-italok és a levegö hütéséhez, amelyeknek az elmúlt évezredekben számos különféle módját alkalmazták (Láng-Jakab, 1984). A hütéstechnika történetében új korszakot jelentenek az elektromos árammal müködő hütőgépek, amelyek elvezettek a CFC használatához. Ezért az ózontörténet első része a 20. század első évtizedeiben kezdődött, amikor kiépültek az első elektromos hálózatok a fejlett ipari országokban. A háztartásokba eljutó elektromos áram lehetőséget adott új típusú háztartási gépek, köztük a hütőgépek használatára is. A hütőgépekben használt hütőfolyadékok 
azonban gyúlékonyak és mérgezőek voltak, ezért súlyos betegségeket és halálos baleseteket is okoztak. A társadalom védelme érdekében az Egyesült Államokban olyan orvosok léptek fel, akik közvetlen kapcsolatban voltak az élö és az elhalálozott betegekkel. Több szakmai fórumon is megfogalmazták aggodalmaikat (Giunta, 2006, 66.). Chicago tiszti föorvosa pedig 1929-ben a városban betiltotta az egyik hütőfolyadék, a metil-klorid használatát. A tiltást megelőző hónapokban a városban patológusok és vegyészek összeállítottak egy listát a hütőfolyadékok miatt meghalt emberekröl, amelyet a város tiszti főorvosa kiegészített a saját listájával. Ezen esetek összegyüjtése után néhány héttel egy házaspár és egyéves gyermekük halt meg hasonló ok miatt Chicagóban (Giunta, 2006, 67.). A Chicagóban történt tiltást és annak okait a sajtón keresztül megismerte az egész ország. Ennek hatására különféle országos szervezetek (The US Public Health Service, Bureau of Standards, Bureau of Mines, American Medical Association) is foglalkoztak a hütőfolyadékok kockázataival, ennek ellenére nem került sor e folyadékok használatának betiltására. A CFC történetével foglalkozó több leírásban is az szerepel, hogy ez a botrány ösztönözte a gyártókat a változtatásra, de Carmen Giunta kutatásai egyértelmủen bebizonyították, hogy a hütőgépek egyik gyártója már a botrány kirobbanása előtt egy évvel megkezdte azokat a kutatásokat, amelyek célja új és biztonságosabb hủtőfolyadék kidolgozása volt. A General Motors vállalatnál működő kutatórészleg vezetője ugyanis már 1928-ban megbízta ifj. Thomas Midgleyt, hogy állítson elő az eddigieknél biztonságosabb hủtőfolyadékot. (A GM tulajdonában lévő vállalat, a Frigidaire gyártott hütőgépeket.) Az új hủtőfolyadék nyilvános bemutatására 1930-ban került sor az Amerikai Kémiai Társaság konferenciáján, és még ugyanebben az évben megjelent az erről szóló tanulmány is (Midgley-Henne, 1930). A halogénezett szénhidrogén (CFC, freon) már nem gyúlékony és mérgezö, ugyanakkor rendkívül stabil vegyület. Thomas Midgley maga úgy mutatta be a kifejlesztett új anyagot egy sajtótájékoztató keretében, hogy meggyújtott egy gyertyát, amit az előzőleg beszívott freongázt kifújva oltott el, ezzel demonstrálva, hogy a freon nem mérgező és nem is gyúlékony (Paulik, 2016). A CFC-ket a hütőiparon kívül számos más területen is jól lehetett alkalmazni, így gyártásuk gyors ütemben növekedett. A CFC-t szakmai elismerés fogadta, és Thomas Midgley elismert kutató lett. Az adott társadalmi és gazdasági körülmények között fel sem merült, hogy a CFC-nek káros következményei lehetnek, mivel a kockázatelemzés módszertanát csak az 1970-es években fogalmazták meg (URL4).

Mindezek alapján kijelenthető, hogy a húszas és harmincas években a társadalmi és gazdasági feltételek az Egyesült Államokban - és más fejlett ipari országokban - még nem tették lehetővé a veszély felismerését és annak elhárítását. Így ha az ózonréteg elvékonyodásának társadalmi okait kutatjuk, akkor azokat a társadalmi folyamatokat kell tanulmányoznunk, amelyek eredményeként kialakultak a modern társadalmak, amelyekben a természet és a társadalom kapcsolata 
alapvetően különbözött a tradicionális társadalmak személetmódjától és gyakorlatától. A változás további következménye volt, hogy a modern társadalmakban megnőtt a városban lakó emberek aránya, akik már nem tudták használni az évezredek alatt kidolgozott természetes hütési módszereket (pincék, vermek, kutak, folyók, patakok stb.), és ezért megnőtt a mesterséges hütés iránti igény. Az ipari forradalom eredményei és a piacgazdaság pedig lehetővé tették, sőt ösztönözték ezen igények kielégítését. A modern társadalmak tudatosan törekednek a természet és a társadalom szétválasztására, ezért törvényszerüen alakulnak ki olyan társadalmi változások, amelyek megsértik a természet törvényeit (Latour, 1999). A modern társadalmak müködése, amelyeknek a szabályozása - néhány kivételtől eltekintve, mint például a gyógyszerek forgalmazása - nem tiltja a természet törvényeinek megsértését, ezért jelentős kockázattal jár. E kockázatok társadalmi és ökológiai következményei gyakran beláthatatlanok. Ilyen kockázatos lépés a CFC kidolgozása és alkalmazása is. Ebből a szempontból a CFC használata hasonlít a fosszilis energiaforrások, a gépkocsik, a repülőgépek, a mobiltelefonok és számos más anyag és eszköz használatához, amelyek a természet határainak átlépéséhez vezettek. Ezt a kockázatot van hivatva csökkenteni az elővigyázatosság elve, amelyet az EU 2007-ben fogadott el. Ennek ellenére számos kockázat azóta is tovább nő. Ezek közül a legismertebb a szén-dioxid-kibocsátás, amely az összes kibocsátás csökkentését célzó erőfeszítés ellenére továbbra is növekszik.

\section{Az ózonréteg védelme érdekében folytatott küzdelem tanulságai}

A továbbiakban azt vizsgáljuk, hogy milyen társadalmi, gazdasági és politikai körülmények járultak hozzá, hogy az ózonréteg védelme érdekében tett erőfeszítések más környezetvédelmi intézkedésekhez képest rövid időn belül eredményt értek el. Az ózonréteg védelme az ökológiai konfliktusok egyik sikertörténete, ezért is érdemes ennek a tanulságait alaposan megvizsgálni. A siker egyik jele, hogy mára már szinte teljesen megszűnt az ózonkárosító anyagok kibocsátása, a másik pedig az, hogy „2009-ben mind a 196 akkori ENSZ-tagállam csatlakozott egy környezetvédelmi megállapodáshoz. A világon jelenleg mintegy 270 környezetvédelmi megállapodás létezik, de ezek közül csak $A z$ ózonréteg védelméröl szóló Bécsi Egyezmény és Az ózonréteget lebontó anyagokról szóló Montreali Jegyzökönyv érte el az univerzális ratifikációt." (Tóth R., 2016, 136.)

Az elért eredmény ellenére, mint ahogy azt korábban is írtuk, az erős UV-B sugárzás továbbra is veszélyt jelent az egész élővilág számára, hiszen az előrejelzések szerint több évtizedig tart, amíg az ózonréteg újból hasonló védelmet nyújt majd, mint a CFC-k használata előtt. Az erős UV-B sugárzáshoz való alkalmazkodás szempontjából ez is a kudarctörténetek közé tartozik (Antal Z., 2016). Az óriási nemzetközi, országos és helyi szintü egészségvédő erőfeszítések ellenére az ezen a téren elért eredmények mérsékeltek (Páldy, 2016). A sikertörténetet be- 
árnyékolja az is, hogy a CFC-ket helyettesítő szintetikus anyagok üvegházhatású gázok (Faragó, 2017).

A szociológia szempontjából ennek ellenére érdemes megvizsgálni azt, hogy az Egyesült Államokban és más országokban milyen társadalmi csoportok vettek részt az ózonréteg védelméért folyó küzdelemben, és hogy minek köszönhető a sikeres védelem.

Az „ózontörténet” második része 1974-ben kezdődött, amikor egymástól függetlenül két tanulmány jelent meg arról, hogy a CFC-k veszélyeztethetik az ózonréteget (Stolarski-Cicerone, 1974; Molina-Rowland, 1974). Ezek az eredmények az Egyesült Államokban gyorsan, még ugyanabban az évben eljutottak az ország politikai vezetőihez és a lakossághoz is. Ebben meghatározó szerepe volt Rowlandnak, aki az egyik tanulmány szerzőjeként mindent megtett annak érdekében, hogy a veszélyre felhívja a figyelmet. Ez a „vészjelzés” rendkívül hatásos volt, amihez több körülmény is hozzájárult. Ezek közé tartozik az, hogy a hetvenes évek elején a környezetvédelem jelentős társadalmi érdeklődést kiváltó új és fontos kérdésként jelent meg. A környezeti kérdések tudatosításában jelentős szerepet töltött be több más fontos esemény, könyv és publikáció mellett az is, hogy 1972-ben szervezték meg az ENSZ égisze alatt az első környezetvédelmi világkonferenciát Stockholmban, és 1972-ben jelent meg A növekedés határai címü könyv (Meadows et al., 1972). Feltételezhető, hogy mindez elösegítette, hogy az ezzel a kérdéssel foglalkozó tudósok között - akik az egész ózonküzdelemben meghatározó szerepet betöltő társadalmi csoporthoz tartoztak - széles körü együttmüködés alakult ki. „Az ózonkérdés mögé igen jelentős multidiszciplináris tudósbázis sorakozott fel: levegőkémikusok, fizikai kémikusok, meteorológusok, sokféle mérnök, rákkutatók, óceánkutatók, biológusok, talajkémikusok, mezőgazdászok, toxikológusok, botanikusok, rovartannal és sok egyébbel foglalkozó kutatók dolgoztak a háttérben" (Tóth R., 2016, 137.). A környezetvédelmi kérdések iránt megnőtt társadalmi érdeklődés fontos jele az is, hogy ekkor alakultak meg az első „,zöld” civil szervezetek az Egyesült Államokban és más fejlett ipari országokban. Az Egyesült Államokban a tudósok és az ebben a küzdelemben meghatározó szerepet betöltő másik társadalmi csoportként részt vevő civil szervezetek között létrejött együttmüködés kulcsfontosságú esemény volt. A civil szervezetek a CFC-t is tartalmazó aeroszolos hajtógázokkal müködő dezodorok és borotvahabok használata ellen bojkottot hirdettek. A bojkott rendkívüli sikere azt mutatta meg, hogy az ózonréteg védelméért folytatott küzdelemnek erős a társadalmi támogatottsága. A tudományos kutatók erőfeszítéseinek, a civil szervezetek akcióinak és a sajtó támogatásának is köszönhető, hogy az ózonréteg védelmét az USA Kongresszusa már 1974-ben napirendre tüzte.

A politikai döntés meghozatalát akkor még megakadályozta, hogy a CFC-k gyártói és forgalmazói - a küzdelemben a tudósokkal és a zöld szervezetekkel szembenálló társadalmi csoport - tiltakoztak az ózonkárosító anyagok betiltása 
ellen. A gyártók a tudományos bizonyítékok hiányára hivatkoztak. Az ózonlyuk létezését bizonyító tudományos eredmények csak hét évvel később, 1985-ben váltak ismertté (Farman et al., 1985). Ennek ellenére a kongresszusi meghallgatás után négy évvel, 1978-ban, az Egyesült Államokban betiltották az aeroszolos hajtógázok használatát. (Elsőként Svédországban, ott ezt a döntést már néhány hónappal korábban meghozták.) Nemzetközi szinten 1987-ben értek el eredményt az ózonréteg védelmével foglalkozó tárgyalások, és a Montreali Jegyzőkönyv aláírása után kezdődött meg a CFC-k gyártásának radikális csökkenése. A kibocsátás értékei ezt követően folyamatosan szigorodtak (Tóth R., 2016; Faragó, 2017).

Az ózontörténetet elemző amerikai kutatók egy része arra a következtetésre jutott, hogy nem lehet egyértelmüen megmagyarázni ezeket a rendkívüli eredményeket. Az 1978-ban meghozott döntésekre is igaz az, amit az 1987-es döntésről írtak: „A Montreali Jegyzőkönyv történelmi jelentőségű volt, messze meghaladta mindazt, amiről a környezetvédők akkoriban úgy gondolták, hogy politikailag lehetséges" (Meadows et al., 2005, 200.). Annak ellenére, hogy nem lehet tudni, hogy végül ezt a döntést miért hozták meg a különböző országok vezetői, bemutatunk két további társadalmi csoportot, amelyek hozzájárultak ennek az eredménynek az eléréséhez. Az egyik csoportba az ENSZ környezetvédelmi programjának (UNEP) „ózonprogramjában” részt vevő és az ezt a programot támogató politikusok tartoznak. „A munkatársak összegyüjtötték és értelmezték a tudományos bizonyítékokat, eljuttatták a kormányokhoz, semleges helyszínt teremtettek a magas szintủ tárgyalásokhoz, és közvetítőként léptek fel. Az UNEP akkori igazgatója, Mostafa Tolba tapasztalt környezetvédelmi diplomatának bizonyult - a szóváltásokban megőrizte semlegességét, és mindenkit emlékeztetett arra, hogy semmilyen rövid távú önző meggondolás nem olyan fontos, mint a Föld ózonrétegének integritása" (Meadows et al., 2005, 199).

A következő csoport tagjai pedig karikaturisták, hiszen feltételezhető, hogy az általuk készített karikatúrák hozzájárultak ahhoz, hogy az Egyesült Államokban már 1978-ban megszületett a döntés. Az Egyesült Államok kormánya akkor még megosztott volt az ózonréteg védelmének fontosságában. „[a] belügyminiszter nyilvánosan kijelentette, hogy az ózonréteg nem okozna problémát, ha az emberek széles karimájú kalapot és napszemüveget viselnének. Az erre a kijelentésre beindult nemzetközi gúnyolódás (beleértve a kalapot és napszemüveget viselő teheneket, kutyákat, fákat és kukoricákat ábrázoló karikatúrákat is) segítette a kormányzat azon tagjait, akik megpróbálták az elnököt rábírni arra, hogy vegye komolyan az ózonproblémát" (Meadows et al., 2005, 199.).

Gyakori érv, hogy ha az ózonréteg védelme érdekében sikerült ilyen rendkívüli eredményt elérni, akkor ez más hasonló veszélyek, például az éghajlatváltozás elhárítása esetében is sikerülhet. Ez az összefüggés azonban nem ilyen egyértelmü. Ezt a sikert több olyan társadalmi, gazdasági és politikai feltétel tette lehetővé, amely „rendkívüli eseménynek” tekinthető. Ehhez mindenképpen hozzájá- 
rult az 1970-1980-as évek reménykedő „környezetvédő hangulata”, amelynek az 1930-as években még az előjelei sem látszottak, és amelyet a környezetvédelmi konfliktusok sorozatos kudarcai a 2000-es évekre jelentősen meggyengítettek. Rendkívülinek tekinthető az is, hogy a társadalom különböző csoportjai a közös cél érdekében megtalálták az együttmüködés lehetőségeit. Az erős társadalmi nyomás kialakításában kulcsszerepet töltöttek be a tudományos kutatók, a politikusok, a civil szervezetek, a karikaturisták és a sajtó is. Az eredmény eléréséhez mindenképpen hozzájárult az is, hogy több kiváló szakember csatlakozott a küzdelemhez, és hogy közülük néhányan felvállalták ennek a kialakult széles körü együttműködésnek a vezetését és koordinálását. De jelentős hatást gyakoroltak a döntés meghozatalára mindazok, akik tudatos vásárlóként „pénz-szavazataikkal” tudták kifejezésre juttatni érdekeiket a gyártókkal és a forgalmazókkal szemben. A nyomásgyakorlásnak ez a módja azért lehetett ilyen eredményes, mert a dezodorok és a borotvahabok könnyen nélkülözhető vagy helyettesíthető fogyasztási cikkek. Az elért eredményeknek további fontos feltétele volt, hogy a CFC gyártói kezdték el előállítani a CFC-t helyettesítő új anyagokat, és így nem szorultak ki erről a piacról. Az egyre szigorúbbá váló döntéseket pedig azért lehetett meghozni, mert az ipar tudott helyettesítő anyagot alkalmazni, így a CFC gyártásának leállítása nem okozott gazdasági veszteséget számukra. Mindezek alapján az Egyesült Államokban meghozott döntés és a Montreali Jegyzökönyv aláírása nem tekinthető más esetekben is alkalmazható ,jó gyakorlatnak”, hanem inkább a szabályt erősítő kivételnek. A fogyasztói társadalmakban érvényesülő „szabály” pedig az, hogy a domináns társadalmi értékek és normák a természet határainak átlépésére ösztönöznek. Az ennek kockázatait felismerő társadalmi csoportok pedig nem elég erősek ahhoz, hogy a természet határainak átlépését megszüntessék.

Ma még nem lehet tudni, hogy az „ózontörténet” hogyan folytatódik, és azt sem, hogy ennek a történetnek hány része lesz még. Lehetséges, hogy mindaz, ami 1930-ban a CFC felfedezésével elkezdődött, további károkat okoz a természetben és a társadalom életében, de elképzelhető az is, hogy ez a történet elvezet annak a felismerésnek a széles körủ elfogadásához, hogy a társadalmak csak akkor képesek fennmaradni, ha figyelembe veszik a természet törvényeit.

\section{IRODALOM}

Antal Z. L. (2016): A Nap éltető és pusztító ereje. In: Antal Z. L. (szerk): A Nap szerepe a társadalom életében. Budapest: Argumentum Kiadó

Bojkov, R. D. - Fabian, P. (eds.) (1989): Ozone in the Stratosphere. Proceedings of the Quadrennial Ozone Symposium 1988 and The Tropospheric Ozone Workshop. Göttingen: A. Deepak Publishing

Confalonieri, U. - Menne, B. - Akhtar, R. et al. (2007): Human Health. In: Parry M. L. - Canziani O. F. - Palutikof J. P. et al. (eds.): Climate Change 2007: Impacts, Adaptation and Vulnerability, 
Contribution of Working Group II to: Fourth Assessment Report of the Intergovernmental Panel on Climate Change. New York: Cambridge University Press, 391-431. https://www.researchgate.net/publication/220042209_Climate_Change_2007_Impacts_Adaptation_and_Vulnerability

El Ghissassi, F. - Baan, R. - Straif, K. et al. on behalf of the WHO International Agency for Research on Cancer Monograph Working Group (2009): A Review of Human Carcinogens-Part D: Radiation. The Lancet, 10, 8, 751-752. https://www.thelancet.com/journals/lanonc/article/ PIIS1470-2045(09)70213-X/fulltext

EPA (2015): Updating Ozone Calculations and Emissions Profiles for Use in the Atmospheric and Health Effects Framework Model. Washington, D.C.: Stratospheric Protection Division Office of Air and Radiation U.S. Environmental Protection Agency. https://www.epa.gov/sites/ production/files/2015-07/documents/updating_ozone_calculations_and_emissions_profiles_ for_use_in_the_atmospheric_and_health_effects_framework_model.pdf

Faragó T. (2017): Áz ózonréteg megmentése. Egy globális környezeti átterhelés évfordulói és tanulságai. Magyar Tudomány, 178, 9, 1105-1113. http://www.matud.iif.hu/2017/09/12.htm

Farman, J. C. - Gardiner, B. G. - Shanklin, J. D. (1985): Large Losses of Total Ozone in Antarctica Reveal Seasonal ClOx/NOx Interaction. Nature, 315, 207-210. DOI: 10.1038/315207a0

Fountoulakis, I. - Bais, A. F. - Fragkos, K. et al. (2016): Short and Long-term Variability of Spectral Solar UV Irradiance at Thessaloniki, Greece: Effects of Changes in Aerosols, Total Ozone and Clouds. Atmospheric Chemistry and Physics, 16, 2493-2505. DOI: 10.5194/acpd-15-357532015, https://bit.ly/2Gaza41

Giunta, C. J. (2006): Thomas Midgley, Jr., and the Invention of Chlorofluorocarbon Refrigerants: It Ain't Necessarily So. Bulletin for the History of Chemistry, 31, 2, http://acshist.scs.illinois. edu/bulletin_open_access/v31-2/v31-2\%20p66-74.pdf

Glandorf, M. - Arola, A. - Bais, A. et al. (2005): Possibilities to Detect Trends in Spectral UV Irradiance. Theoretical \& Applied Climatology, 81, 33-44. DOI:10.1007/s00704-004-0109-9

IARC (1992): Monographs on the Evaluation of Carcinogenic Risks to Humans. Vol. 55. Solar and Ultraviolet Radiation. Lyon: IARC, https://monographs.iarc.fr/iarc-monographs-on-theevaluation-of-carcinogenic-risks-to-humans-66/

Láng L. - Jakab Z. (1984): Hütéstechnika. (ford. Gecser O.) Budapest: Müszaki Könyvkiadó

Latour, B. (1999): Sohasem voltunk modernek. Budapest: Osiris Könyvkiadó

Meadows, D. H. - Meadows, D. L. - Randers, J. et al. (1972): The Limits to Growth. Potomac Associates, http://www.donellameadows.org/wp-content/userfiles/Limits-to-Growth-digitalscan-version.pdf

Meadows, D. - Randers, J. - Meadows, D. (2005): Visszatérés a határon túlról: az ózontörténet. In: Meadows, D. - Randers, J. - Meadows, D.: A növekedés határai - Harminc év múltán. (ford. Déri A.) Budapest: Kossuth Kiadó

Midgley, T., Jr. - Henne, A. L. (1930): Organic Fluorides as Refrigerants. Industrial and Engineering Chemistry, 1930, 22, 542-545. DOI: 10.1021/ie50245a031

Molina, M. J. - Rowland, F. S. (1974): Stratospheric Sink for Chlorofluoromethanes: Chlorine Atom-catalysed Destruction of Ozone. Nature, 249, 810-812. https://www.nature.com/articles/249810a0.pdf

Páldy A. (2016): A Nap gyógyító és megbetegítő hatásai. In: Antal Z. L. (szerk.): A Nap szerepe a társadalom életében. Budapest: Argumentum Kiadó, 148-174.

Paulik K. (2016): „Már csak nézhetünk, mint a moziban?” Interjú Gelencsér Andrással, a Pannon Egyetem rektorával, az MTA Levegőkémiai Kutatócsoportjának vezetőjével. Innotéka Magazin, 2016. augusztus-szeptember, 30-35. http://www.innoteka.hu/cikk/mar_csak_nezhetunk_ mint_a_moziban.1380.html 
Reichrath, J. - Nürnberg, B. (2009): Cutaneous Vitamin D Synthesis Versus Skin Cancer Development. The Janus Faces of Solar UV-Radiation. Dermato-Endocrinology, 1, 5, 253-261. https:// www.ncbi.nlm.nih.gov/pmc/articles/PMC2836430/

Schmalwieser, A. W. - Gröbner, J. - Blumthaler, M. et al. (2017): UV Index Monitoring in Europe. Photochemical \& Photobiological Sciences, 16, 1349-1370. DOI: 10.1039/c7pp00178a, https:// www.researchgate.net/publication/319107889_UV_Index_monitoring_in_Europe

Stolarski, R. S. - Cicerone, R. J. (1974): Stratospheric Ozone Destruction by Man-Made Chlorofluoromethanes. Science, 185, 4157, 1165-1167. DOI: 10.1126/science.185.4157.1165, https:// escholarship.org/uc/item/5hk1w60k

Takács I. - Benkő I. - Toldy E. (2012): Hazai konszenzus a D-vitamin szerepéről a betegségek megelőzésében és kezelésében. Orvosi Hetilap, 153, Suppl. 2, 5-26. DOI: 10.1556/OH.2012.29410, http://repo.lib.semmelweis.hu/bitstream/handle/123456789/4215/oh.2012.29410.pdf?sequen$\mathrm{ce}=1$

Tóth R. (2016): Egy eredményes válasz az erős napsugárzás kockázatainak csökkentésére: A Montreali Jegyzőkönyv. In: Antal Z. L. (szerk.): A Nap szerepe a társadalom életében. Budapest: Argumentum Kiadó

Tóth Z. (2016): A napból érkező sugárzások hatása a Földre. In: Antal Z. L. (szerk.): A Nap szerepe a társadalom életében. Budapest: Argumentum Kiadó

Tóth Z. (2017): A Napból érkező ultraibolya sugárzás nagy pontosságú mérésének problémái. Fizikai Szemle, LXVII, 7-8, 232-239.

Tóth Z. - Fekete D. (2018): Variation of Broad Band and Spectral UV Irradiances in Hungary during the Period 1995-2017. In: Abstracts. European Conf. on Solar UV Monitoring, 12-14 Sept. 2018, Vienna, Austria.

URL1: http://www.cancercode.org/code_06.htm

URL2: Ultraibolya sugárzás és egészség. WHO Ténylap No 305. 2009. December (Ultraviolet Radiation and Human Health Fact Sheet No 305 December 2009. https://cetesb.sp.gov.br/laboratorios/wp-content/uploads/sites/24/2013/11/uv_saude_ingles.pdf

URL3: Climate Change, Human Health Risk and Responses. (2003) http://www.who.int/globalchange/climate/en/chapter3.pdf

URL4: Evolution and Use of Risk Assessment in the Environmental Protection Agency: Current Practice and Future Prospects. https:/www.ncbi.nlm.nih.gov/books/NBK214619/ 